University at Buffalo School of Law

Digital Commons @ University at Buffalo School of Law

\title{
Environmental Certification Systems and U.S. Environmental Law: Closer than You May Think
}

\author{
Errol E. Meidinger \\ University at Buffalo School of Law
}

Follow this and additional works at: https://digitalcommons.law.buffalo.edu/journal_articles

Part of the Environmental Law Commons, and the Legislation Commons

\section{Recommended Citation}

Errol E. Meidinger, Environmental Certification Systems and U.S. Environmental Law: Closer than You May Think, 31 Envtl. L. Rep. News \& Analysis 10162 (2001).

Available at: https://digitalcommons.law.buffalo.edu/journal_articles/543

\section{C) ${ }_{\text {COPYRIGHT }}^{\text {N }}$}

This Article is brought to you for free and open access by the Faculty Scholarship at Digital Commons @ University at Buffalo School of Law. It has been accepted for inclusion in Journal Articles by an authorized administrator of Digital Commons @ University at Buffalo School of Law. For more information, please contact lawscholar@buffalo.edu. 


\title{
Environmental Certification Programs and U.S. Environmental Law: Closer Than You May Think
}

\author{
by Errol E. Meidinger ${ }^{1}$
}

I. Introduction . . . . . . . . . . . . . . . . . . . 10162

II. Environmental Certification Programs . . . . 10163

A. Standard Setting . . . . . . . . . . . . . 10163

B. Adjudication and Enforcement . . . . . . . 10164

C. Certification Systems and Legal Systems. . 10164

1. Legal Systems. . . . . . . . . . . . . . . . 10165

2. Certification Systems . . . . . . . . . . . 10165

III. Legal Incorporation of Certification

Systems . . . . . . . . . . . . . . . . . . . . 10166

A. Legal Requirement of Certification . . . . . . 10166

B. Official Promotion of Certification . . . . . . 10168

C. Express Adoption of the Same or Substantially

Similar Standards . . . . . . . . . . . . . 10169

D. Indirect Adoption Through "Environmental"

Laws . . . . . . . . . . . . . . . . . 10170

E. Indirect Adoption Through "Nonenvironmental"

Laws . . . . . . . . . . . . . . . . . . 10171

1. Tort Law. . . . . . . . . . . . . . . . . 10171

2. Property Law . . . . . . . . . . . . . 10173

3. Tax Law . . . . . . . . . . . . . . . . . 10173

4. Information Regulation . . . . . . . . . 10174

5. Financial Regulation ... . . . . . . . . 10174

6. Trade Law . . . . . . . . . . . . . . . 10174

F. Forbearance . . . . . . . . . . . . . . . 10175

IV. Legal Control of Certification Systems . . . 10175

A. Informal Steering . . . . . . . . . . . 10175

B. Direct Regulation . . . . . . . . . . . . . 10175

C. Inhibition of Certification Systems . . . . . 10176

1. National Trade Regulation . . . . . . . . 10176

1. Errol E. Meidinger is Professor and Vice Dean of Law at the State University of New York at Buffalo. This Article, (C) Errol E. Meidinger 2000 , is a revision of a paper presented to the CAVA workshop on "The Integration of Voluntary Approaches Into Existing Legal Systems," held in Brussels, Belgium, February 24-25, 2000. Helpful comments by workshop participants, and by Robert Bell, Guyora Binder, Barry Boyer, Ben Cashore, Chris Elliott, Ira Feldman, Shubha Ghosh, Elizabeth Mensch, Jack Schlegel, Margaret Shannon, John Shoaff, David Westbrook, and Jim Wooten are gratefully acknowledged, as is research assistance by Patrick Omilian. The paper was written while the author en joyed the privilege of being a Fulbright Senior Scholar in the supportive environment of the Institute for Forestry Economics at the University of Freiburg, Germany. Professor Meidinger can be contacted by e-mail, eemeid@buffalo.edu, or on the Internet, http://www.law.buffalo.edu/ homepage/eemeid.

2. See Forest Stewardship Council Website, at http://www.fscoax.org/ principal.htm (last visited Nov. 29, 2000) [hereinafter FSC Website]. For a recent high profile article on the FSC, see Jim Carlton, How Home Depot and Activists Joined to Cut Logging Abuse: If a Tree Falls in the Forest, the Small, Powerful FSC Wants to Have Its Say, WaLl St. J., Sept. 26, 2000 , at Al. For general overviews of forest certification programs, see, e.g., Steven Bass, Introducing Forest Certification, Report of the International Institute for Environment and Development (1997), at
2. International Trade Regulation . . . . . . 10176

V. Conclusions . . . . . . . . . . . . . . . 10176

A. Patterns of Legal Incorporation . . . . . . . 10176

B. Implications . . . . . . . . . . . . . 10177

\section{Introduction}

In rapidly growing numbers, business firms are committing to meet environmental standards set by nongovernmental environmental certification programs. Such programs claim to harness the incentives of the market to promote the public interest. They typically define the environmental standards that firms must meet and establish organizational mechanisms for achieving and "certifying" compliance. Depending on the program, firms are entitled to signal their certification status by displaying labels on their literature, facilities, or products. Examples of important environmental certification programs include the Forest Stewardship Council's (FSC's) well-managed forests program, ${ }^{2}$ the International Organization for Standardization (ISO) 14001 environmental management program, ${ }^{3}$ and the chemical industry's Responsible Care ${ }^{\circledR}$ program. ${ }^{4}$

Although environmental certification programs have immense potential to reshape environmental management practices and their affiliated legal rights and duties, American environmental lawyers have largely ignored them. It is difficult to say why. Perhaps they assume from decades of experience that important environmental mandates necessarily come from governments. Perhaps they are constitu-

http://www.efi.fi/publications/Discussion_Papers/01.pdf (last visited Nov. 28, 2000), or Errol Meidinger, "Private" Environmental Regulation, Human Rights, and Community, 6 BufF. ENVTL L.J. 132(1999), available at http://www.law.buffalo.edu/homepage/eemeid/scholarship/hrec.pdf (last visited Oct. 20, 2000) [hereinafter Private Environmental Regulation]. There are numerous other private environmental certification programs. Many of the older ones concentrate on food labeling, particularly in Europe. Many of the newer ones focus on particular sectors of environmental management, such as forestry, fishing, chemical production, and so on.

3. See ISO and the Environment, at http://www.iso.ch/9000e/isoanden. $\mathrm{htm}$ (last visited Nov. 28, 2000). For general overviews, see Bass, supra note 2; Private Environmental Regulation, supra note 2.

4. The American Responsible Care $®$ program is described at American Chemistry Council, Good Chemistry, at http://www.cmahq.com (last visited Nov. 27, 2000). The Canadian program-the first in the world - can be found at Voluntary Codes-Executive Summaries, at http://strategis.ic.gc.ca/SSG/ca00797e.html (last visited Nov. 27, 2000). For a general overview, see Neil Gunningham, Environment, Self-Regulation, and the Chemical Industry: Assessing Responsible Care, 17 Law \& PoL'y 57 (1995). 
tionally different from corporate and securities lawyers, who, over the years, have made much more extensive use of nongovernmental ordering mechanisms. In any event, the nearly exclusive focus of American environmental lawyers on government mandates is increasingly anachronistic, given the apparent incapacity of legislatures to seriously reassess existing laws and the sluggishness of administrative agencies in restructuring regulatory frameworks.

This Article argues that environmental certification programs are likely to become important engines of change in American environmental law, and that they deserve the serious attention of environmental lawyers. Section II describes common features of environmental certification programs to date, and compares them to governmental legal systems. Sections III and IV review areas of law likely to be implicated by certification programs, and describe how they may relate to certification. Section $V$ offers some concluding thoughts about the implications of certification programs.

\section{Environmental Certification Programs ${ }^{5}$}

\section{A. Standard Setting}

Environmental certification programs seek to verify for a broader public ${ }^{6}$ that the activities of certified enterprises are environmentally appropriate. Of course, the first rub comes in defining "appropriate." Certification programs follow two basic approaches. In the first, the certification program sets substantive performance standards to be met by all certified firms. The FSC, for example, requires that "forest management shall conserve biological diversity and its associated values, water resources, soils, and unique and fragile ecosystems and landscapes, and, by so doing, maintain the ecological functions and the integrity of the forest." This requirement is further defined in national and regional standards, which establish concrete criteria and indicators for compliance. ${ }^{7}$ FSC certification also requires firms to respect applicable environmental laws, protect the well-being of workers and communities, and so on. ${ }^{8}$ The FSC's primary

5. This paper occasionally substitutes the term "certification system" for "certification program." While the term "program" typically refers to a specific, operating organization, the term "system" refers to its more abstract structure of actors and their relationships, often extending well beyond the organization. Many certification programs are based in industry or trade groups, thereby falling into the "self-regulation" category as developed by much scholarship on regulatory institutions (e.g., IAN Ayres \& John BratthwaIte, Responsive Regulation: TRANSCENDing THE Deregulation Debate (1992); Margot Priest, The Privatization of Regulation: Five Models of Self-Regulation, 29 OTTAWA L. REv. 233 (1997-1998)). Many of the newer and most innovative programs, however, are based on nongovemmental organizations or technical standard-setting organizations.

6. The question of what "public" is the intended audience is of ten quite important to the operation of a certification program, but cannot be gone into here. Potential audiences include environmental activists, consumers, intermediate manufacturers or retailers, local communities, and society as a whole. For a brief discussion of the roles audiences can play in certification dynamics, see Benjamin Cashore, Legitimacy and the Privatization of Environmental Governance: Exploring Forest Certification (Eco-Labeling) in the U.S. and Canadian Forest Sectors, GOVERNANCE J. (forthcoming 2001) (manuscript at 8-10) (copy on file with author). competitor in the United States, the American Forest \& Paper Association's (AF\&PA's) Sustainable Forestry Initiative (SFI), has set substantive environmental standards that mimic the FSC's to some extent, but are more favorable to industrial forest management. The SFI program does not attempt to integrate social justice concerns. ${ }^{9}$

The second approach to certification is essentially procedural, requiring firms to implement environmental management systems (EMSs) with defined responsibility structures for planning, operations, monitoring, corrective action, and so on. Thus, firms may set their own substantive standards, but are required to institute organizational mechanisms for achieving them. The cardinal example is the ISO 14001 program. Its motor is the "continuous improvement" requirement. ${ }^{10}$ The underlying assumption is that dynamic EMSs will achieve superior environmental performance over time, while facilitating greater efficiency and adaptability than substantive standards. It is of course possible to combine substantive and procedural approaches, and many systems do so to some extent. The FSC, for example, has a modest EMS requirement, ${ }^{11}$ and the Canadian Standards Association places heavy stress on the EMS while incorporating modest substantive standards. ${ }^{12}$

Certification programs generally have formal arrangements for setting and revising standards. Programs sponsored by industry associations tend simply to employ the general decision procedures of the associations. Other programs, such as the ISO and the FSC, have much more elaborate arrangements. The FSC, for example, has a constitutional structure with an international "general assembly" representing economic, environmental, and social interests in equal proportions, and giving northern (developed) and southem (developing) societies equal voting power within each interest. ${ }^{13}$ It also provides for national and regional legislative bodies to define place-based forest management standards and criteria, which become applicable on approval by the United Nations General Assembly. The central and regional legislative bodies have promulgated a large number of rules governing forest management, its evalua-

\section{See Appendix.}

8. The effort to integrate environmental, economic, and social justice criteria in the same standard is of course highly ambitious, perhaps more so than most governmental regulatory programs. For an analysis of how the FSC pursues the trilateral agenda, see Private Environmental Regulation, supra note 2.

9. See generally Sustainable Forestry Initiative Program, at http://www.afandpa.org/forestry/forestry.html (last visited Nov. 28, 2000). See also Private Environmental Regulation, supra note 2.

10. See ISO, INTERNATIONAL STANDARD 14001, ENVIRONMENTAL MaNAgement Systems-SPECIFICATION With GUIDANCE fOR USE $\$ 4.2$.

11. Private Environmental Regulation, supra note 2.

12. See Chris Elliott, Forest Certification: Analysis From a Policy Network Perspective 308-9 (1999) (unpublished Ph.D. Thesis, École Polytechnique Fédérale de Lausanne) (on file with author).

13. For a thorough description of the FSC structure, see Private Environmental Regulation, supra note 2. 
tion, and certification, which closely resemble what legal scholars would ordinarily call legislation. ${ }^{14}$

Finally, it is important to note that the standards promulgated by different certification systems interact. Sometimes systems simply borrow good ideas from one another. Often, however, they design standards strategically to compete with each other. Their competitive strategies appear designed, among other things, to attract new adherents, to blunt the attractiveness of other programs, and to define master social metaphors, such as ecosystem health, sustainability, and corporate responsibility. ${ }^{15}$ The standards must be understood, therefore, as participating in a larger social dialogue regarding standards for acceptable and unacceptable behavior.

\section{B. Adjudication and Enforcement}

As the broad popularity of EMSs suggests, certification programs put considerable stress on implementation mechanisms. There is broad agreement among programs that internal organizational controls are necessary for firms to achieve and maintain compliance. There is much contention, however, about what kinds of external mechanisms are necessary. The FSC has generally taken the lead with the position that independent, third-party auditors are essential. The ISO imposes a similar requirement for 14001 registration. Industry groups such as the AF\&PA and the Chemical Manufacturers Association have resisted the idea, arguing that a firm's commitment to meet the standard should be sufficient. Over time, industry programs seem to be retreating, recognizing that self-certification suffers from inherently limited public credibility. The AF\&PA, for example, recently instituted a "voluntary verification" program, in which member firms may arrange for audits by third-party verifiers if they wish. ${ }^{16}$

The growth of environmental certification programs has spawned a growing profession of third-party environmental certifiers, many of whom conduct certifications under a variety of systems. These certifiers seem to draw their

14. FSC Website, supra note 2. Much but not all of FSC legislation is applicable to forest management. Some of it also defines how the various bodies in the FSC system are to operate, as would be the case with governmental legislation. Edward Rubin, Law and Legislation in the Administrative State, 89 ColuM. L. REv. 369, 374 (1989).

15. As in business competition, certification programs also enjoy strategic possibilities for cooperative agreements, alliances, mergers, and so on. One ongoing discussion, ordinarily regarding certification programs in the same sector, concerns "mutual recognition" of one program by another. Only a few examples have occurred to date, but many more seem possible. Multi-country certification alliances are also occurring, as is being demonstrated by the creation of the 14-nation Pan European Forest Certification Council. See Pan European Forest Certification Website, at http://www.pefc.org (last visited Nov. 28, 2000). Cross-sector alliances among certification programs are also emerging. One of the most intriguing is the International Social and Environmental Accreditation and Labeling Alliance (ISEAL), which includes the Conservation Agriculture Network, Fairtrade Labeling Organizations, FSC, International Federation of Organic Agriculture Movements, International Organic Accreditation System, and Social Accountability International, which are seeking to coordinate their standard-setting and enforcement strategies. Presentation by James Sullivan and Pat Mallet, Forest Stewardship Council Annual Meeting, Oaxaca, Mexico, Nov. 11, 2000, available at http://www.isealalliance.org (visited Oct. 25, 2000). value from a combination of professional expertise, experience with a broad variety of certification cases, and careful justification of their decisions under applicable standards. Viewed from one angle, although they would undoubtedly resist this characterization, certifiers can be seen as 21 st century analogues to the itinerant justices sent out by ancient English monarchs to ensure that affairs on the land were conducted as expected. ${ }^{17}$ From a more prosaic perspective, they can be viewed as independent contractors performing adjudication and enforcement functions quite comparable to those of modem administrative law judges. ${ }^{18}$

Perhaps the most striking difference between certifiers and administrative law judges is that certifiers are generally paid by the firms being certified, rather than by govemment. Their independence and objectivity are thus continually subject to challenge. Given this vulnerability, it is interesting that environmental certification systems have not adopted what appears to be the most important mechanism for protecting the legitimacy of govemment regulatory agencies in the modern era: public access to information. To date, environmental certification programs have asserted that their labels fulfill all legitimate public information requirements. Pressures for greater information-sharing and transparency are growing, however, and certification programs seem likely to respond to them over time.

\section{Certification Systems and Legal Systems}

With their standard-setting, adjudication, and enforcement mechanisms, certification programs bear a striking resemblance to government regulatory programs. Yet, because of their apparently autonomous and voluntary nature, certification programs are often conceptualized as "unilateral
16. See Statement of Expert Review Panel Chairman Paul Hansen, 1999 5th Annual Progress Report, AF\&PA Sustainable Forestry Initiative 2, available at http://www.afandpa.org/forestry/forestry.html (last visited Nov. 28, 2000).

17. See, e.g., S.F.C. Milsom, Historical Foundations of THE Common Law 25-36 (2d ed. 1981).

18. The certifiers act as adjudicators in that they are charged with determining whether applicants for certification meet the various ecological, operational, economic, and social criteria. Certifiers also actas enforcers. In the FSC system, for example, they are charged with on-going monitoring of firms that receive certification, and can revoke certificates if forest management falls below set standards. As in many regulatory regimes, considerable responsibility for collecting information and reporting on compliance falls to regulated firms. FSC certifiers also exercise a great deal of discretion and judgment in determining whether individual forest management operations meet the standards for certification. This is due to both the inherent complexity of forest management and the multiple environmental, social, and economic goals of the certification regime. As is often the case with govemment agencies, many certification programs have standards and procedures for accrediting the certifiers who determine whether management practices meet their standards. 
commitment"19 programs separate and distinct from legal systems. In fact, however, certification programs are both similar to and deeply intertwined with traditional legal systems. In addition to using law to organize themselves and control their members, certification programs also rely on the fear of intensified legal regulation to attract participants. Perhaps more importantly, certification programs can have a significant influence on the content and implementation of legal mandates. This influence is likely in turn to prompt legal systems to seek ways of influencing or regulating certification systems. In tracing the paths and forms that such interactions are likely to take, it is helpful to start by comparing the basic elements of legal systems and certification systems.

\section{Legal Systems}

Of course, the definitions of "law" and "legal system" have been much disputed over the years, and will not be resolved here. For present purposes, it is sufficient to note that there is widespread acceptance that legal systems have the following features ${ }^{20}$ :

(1) Legislative bodies, often representing defined interests, make rules governing actors within their jurisdiction.

(2) Adjudicative bodies determine the applicability of rules in particular cases. In doing so they often give further definition to rules.

(3) Enforcement bodies and

(a) gather information on compliance with rules,

(b) use sanctions (punishments and rewards), to promote compliance.

(4) The legal bodies operate under rules, ordinarily goveming both their composition and procedures, which often include opportunities for public participation.

(5) Actions taken by legal bodies are not fully deter-

19. This categorization reflects the work of the Concerted Action on Voluntary Approaches (CAVA) project, a European Union-supported effort to develop a research network and a body of research on the use of "voluntary approaches" to improve environmental management. CAVA: Concerted Action on Voluntary Approaches, at http://www.ensmp.fr/Fr/ CERNA/CERNA/Progeuropeens/CAVA/Index.html (last visited Nov. 25, 2000). See Steven Baeke et al., The Nature of Voluntary Approaches: Empirical Evidence and Patterns: Literature Survey, CAVA Working Paper No. 99/08/3, August 1999; ORganization FOR ECONOMIC CoOperation \& Dev., Voluntary APPROACHES For ENVIRONMENTAL Policy: AN Assessment (1999). Certification systems are a special kind of unilateral commitment program, since they do not claim to be "one shot" efforts, but rather set up frameworks for long-term policy development and implementation.

20. See, e.g., Joseph RAz, The Concept of A Legal System: AN InTroduction to THE Theory of Legal System (2d ed. 1980). Although western legal terms such as legislation and adjudication are used here, these terms need not be used within legal systems. The key idea is that legal systems have ways of formulating rules, determining their applicability, applying sanctions, and so on.

21. The amount of discretion, however, may often look larger when viewed from the perspective of rules than when viewed within a social context including cultural assumptions, shared operating procedures, and the like. See, e.g., Errol Meidinger, Regulatory Culture: A Theoretical Outline, 9 LAw \& PoL'Y 355 (1987); Edward L. Rubin, Discretion and Its Discontents, 72 ChI.-Kent L REv. 1299 (1997).

22. See, e.g., Hans Kelsen, General Theoryof Law and the State mined by rules; they also involve the exercise of judgment and discretion. ${ }^{21}$

(6) Sovereignstates provide the primary authority and implementation mechanisms, largely financed by taxes.

The last criterion is maintained by many, ${ }^{22}$ but not all $^{23}$ legal theorists. It has long faced problems regarding how democratic a state must be for its rules to qualify as law. ${ }^{24}$ More recently, the growth of a global order transcending individual states yet enacting rules that operate like laws has created problems for this conception. ${ }^{25}$ These issues receive further attention in the conclusion of this Article.

\section{Certification Systems}

Although there is no uniform definition of a certification system, and existing programs that are classified as certification systems vary considerably, most systems include the following elements:

(1) Standard setting bodies operating with defined membership and decision processes. These can be sector-specific industry groups (e.g., the Chemical Manufacturers Association), general industrial standard setting federations (e.g., the ISO), ${ }^{26}$ or multi-interest stakeholder groups (e.g, the FSC).

(2) Standards for certification,

(a) These follow either or both of two general approaches:

(i) Substantive performance standards (the FSC approach);

(ii) Environmental management_system standards (the ISO approach);

(b) Certification can attach to an enterprise, a product, or both, depending on the program.

(3) Organizational mechanisms for certifying compliance of individual firms with applicable standards, which center on:

(a) Information systems maintained by firms

(b) Professional certifiers exercising considerable

(1945). Kelsen, like most western legal theorists of the late 19th and 20th centuries, argued that law must involve a threat of punishment by the state.

23. See, e.g., Friedrich Charles von Savigny, Of the Vocation of OUR AGE FOR LEgISLATION AND JURISPRUDENCE (Abraham Hayward trans., Amo Press 1975) (1831). Savigny argued that law "is first developed by custom ... next by jurispnudence-everywhere, therefore, by internal silently-operating powers, not by the arbitrary will of a law-giver." Id. at 30 . He was arguing against the creation of a national law for Germany, and in favor of preserving local variation.

24. See, e.g., Herman Heller, The Nature and Structure of the State, 18 CARDozo L. Rev. 1139 (1996); Frank Michaelman, Law's Republic, 97 YALE L.J. 1493 (1988).

25. See, e.g., Gunther Teubner, Breaking Frames: The Global Interplay of Legal and Social Systems, 45 AM. J. CoMP. L. 149, 157-59 (1997).

26. To an important degree, the existence of the ISO and its national affiliates dates back to a time when the primary purpose of nongovermmental standard setting was to help buyers and sellers achieve shared understandings of what standards the products they bought and sold would meet.

The geographic scope of certification programs varies greatly. The FSC and the ISO are global. Other programs, such as the Pan European Forest Certification Council, are regional. See Pan European Forest Certification Website, supra note 15. The AF\&PA is national program based in the United States. There are also a number of sub-national certification programs, though they are likely to be viable only in the narrowest markets. 
site-specific discretion. ${ }^{27}$

(4) Provisions for public participation. ${ }^{28}$

(5) Mechanisms for sanctioning_non-compliance, ${ }^{29}$ usually:

(a) withdrawal of certification, and/or

(b) expulsion from membership in a group.

In sum, environmental certification programs have most of the same basic organizational elements of legal systems. What they generally lack is a command from a sovereign directing all management organizations in a given category to achieve certification standards, and subjecting them to sovereign-imposed penalties for failure to do so. As indicated above, certification systems are generally characterized as "voluntary." Firms subscribe to them because they determine that it is in their interest to do so. Yet it is increasingly common to describe environmental certification as a "de facto requirement" for doing business in many jurisdictions. ${ }^{30}$ When interviewed, corporate officials often state that they feel they have "no real choice" but to become environmentally certified. The reasons they give vary, and include such factors as avoiding intensified government regulation, maintaining or expanding market share, averting negative publicity, improving community and/or employee relations, improving organizational efficiency, meeting demands of up-stream sellers or down-stream buyers, obtaining higher prices, avoiding legal liability, increasing shareholder confidence, and so on. Although many of these reasons do not flow directly from government regulation, they do suggest a context in which industrial enterprises view environmental certification as a mandatory condition of operating in modern society. Moreover, some certified large firms have begun mandating certification for their suppliers. Ford, General Motors, and Daimler-Chrysler, for example, have all established timetables for having all of their suppliers ISO 14001 certified. ${ }^{31}$ In addition, programs such as SFI require that members undertake to conduct training programs for all of the contractors who supply them; they also encourage "licensing" of non-members who wish to be certified. ${ }^{32}$

Thus, the gap between coercive government regulation and "voluntary" private certification is not as wide as

\section{See supra note 19.}

28. Public participation provisions vary considerably among programs and often seem designed to limit rather than expand the public role in standard setting and certification. See Private Environmental Regulation, supra note 2.

29. There is no systematic information on how often certification systems actually employ sanctions. My impression from communicating with knowledgeable sources is that sanctions are rarely imposed.

30. See, e.g., Virginia Haufler, Private Sector International Regimes, 4 Polibus 2 (1998); Naomi Roht-Arriaza, Private Voluntary Standard-Setting, the International Organization for Standardization, and International Environmental Lawmaking, in 6 YEARBOOK OF INTERNATIONAL ENVIRONMENTAL LAW 107, 119 (Günther Handl ed., 1995); Joel Ticknor, ISO 14000: Will It Deter Cleaner Production?, 8 New Solutions 285, 286 (1998).

31. See the news releases collected at ISO 14000-What's New, at http://www.isol 4000.com/WhatsNew (last visited Nov. 25, 2000).

32. See Sustainable Forestry Initiative Program, supra note 9.

33. As is noted in section V, the list is largely limited to "legal" might be expected. Moreover, many of the reasons given to explain the growth of certification have at different times in history been grounds for expanded government regulation. It is not surprising, therefore, that complex relationships might emerge between certification and legal systems.

The next two sections catalog some of the legal channels through which those relationships can operate. Section III lists legal mechanisms that seem largely receptive to certification systems, while Section IV lists ones that seem more resistant. It is important to note, however, that most of the legal mechanisms described below could in principle be used either to promote or to undermine certification programs, or indeed to promote some and undermine others.

\section{Legal Incorporation of Certification Systems}

Environmental certification programs can be incorporated in law through a variety of means. ${ }^{33}$

\section{A. Legal Requirement of Certification}

The most obvious means of incorporating certification into law is for an authoritative legal body to require that firms operating within its jurisdiction be certified. That legal body could be either a legislature or an administrative agency with a broad mandate to achieve environmental improvement. There is much to commend this strategy, since it can mandate global, state-of-the-art standards, place much of the administrative burden on non-state bureaucracies funded by the enterprises involved, and garner some of the political legitimacy of environmental nongovernmental organizations for the government regulatory system. The downsides include a reduction in government control over regulatory policy (although the government retains the option of imposing and administering its own standards) and potentially higher costs of operation for enterprises than if government agencies bear the costs of administration. ${ }^{34}$ To date there are few examples of governments requiring environmental certification ${ }^{35}$ : the Brazilian state of Acre recently made FSC certification a requirement for practicing forestry in the state, ${ }^{36}$ and Zimbabwe has incorporated ISO

mechanisms as conceived in traditional legal scholarship. Other important micro and macro dimensions of incorporation should also be considered.

34. Of course there are contending normative arguments regarding who should bear administrative costs. One position is that the public should bear them, since the certification program promotes the public interest in an improved environment. The other is that the enterprise should bear them, ordinarily through increased costs to its consumers, since it creates the situation requiring the regulatory program. This is the so-called polluter-pays principle. The position one takes on these questions depends on the entitlement structure from which one begins the analysis.

35. Requirements for narrower kinds of certification, such as standards for pollution control equipment, operator training, and maintenance programs, appear to be quite common in environmental regulation. Personal communication, John Shoaff, Pollution Prevention Division, U.S. EPA (July 20, 2000).

36. Personal communications, Professor Michel Becker, Institute for Forest Policy, University of Freiburg and Dr. Dietrich Burger, German Organization for Technical Cooperation (GTZ), Frankfurt, Germany (Feb. 28, 2000). 
14001 into its regulatory system. ${ }^{37}$ Yet, it seems likely that their numbers will grow as the certification systems mature and become better known.

Provided they have broad enough authority, administrative agencies could also legally mandate certification. Where agencies are limited to traditional administrative mechanisms, legislatures could give them added authority to require certification. Agencies mandating certification would most likely use rules in conjunction with contracts. A rule, for example, could simply require specified types of firms operating in the jurisdiction to be certified by a specific program or by one of several eligible programs. Contracts could then be used by the agency to achieve a degree of control over the certification programs without going through more cumbersome rulemaking or adjudication procedures. While these methods are being used in some other areas of privatization, such as prisons and healthcare, ${ }^{38}$ their extension to environmental regulation would probably be a new development. It should be noted, however, that U.S. environmental laws already give a large role to private enforcers through "citizen suit" provisions, which allow interested parties to bring enforcement actions for violations of federal or state pollution control standards. ${ }^{39}$

In the U.S. legal system, a law requiring certification by a nongovernmental entity would probably face legal challenges based on the "nondelegation doctrine," which is generally held to prohibit the delegation of law making powers to private actors. ${ }^{40}$ There are several solutions, however, the simplest of which is for the legislature to review the standards involved and to enact them as its own if it so

37. See Paulette L. Stenzel, Can the ISO 14000 Series Environmental Standards Provide a Viable Alternative to Government Regulation?, 37 AM. Bus. L.J. 237, 276(2000). Whether these examples are evidence that developing countries are especially likely to adopt private environmental certification requirements in their regulatory systems can only be known over time.

38. See generally Jody Freeman, The Private Role in Public Governance, 75 N.Y.U. L. REv. 543 (2000); Laurent Hourcle \& Frederick J. Lees, Applicability of ISO 14000 Standards to Government Contracts, 27 ELR 10071 (Jan. 1997).

39. See generally Barry Boyer \& Errol Meidinger, Privatizing Regulatory Enforcement: A Preliminary Analysis of Citizen Suits Under Federal Environmental Laws, 35 BUFr. L. REv. 834-965 (1985). Government agencies can exercise control over such actions either by taking over prosecution of the case or by intervening in the private enforcement action. If the govermment does take over prosecution of the case, the private litigant retains the right to continue participating as an intervenor. Id.

40. The key decision was Carter v. Carter Coal Co., 298 U.S. 238 (1936), which invalidated a New Deal statute allowing bituminous coal producers to elect boards to set minimum prices for coal in their districts. The court stressed the possible conflicts of interests of business representatives regulating others in their industry. For a contemporary analysis of delegations outside govermment, see Harold J. Krent, Fragmenting the Unitary Executive: Congressional Delegations of Administrative Authority Outside the Federal Government, 85 Nw. U. L. REv. 62 (1990).

41. Interestingly, one problem that could arise derives from the fact that many nongovemmental standards are copyrighted. The ISO, for example, vigorously enforces the copyrights on its thousands of standards and guidelines. Together with its member organizations, the ISO appears to depend on the sale of those publications for significant revenue. One can only speculate how the ISO and other standard-setting organizations chooses. ${ }^{41}$ It might even suffice for the legislature to reserve the power to review the nongovernment rules and to provide for judicial review of them under general administrative law. ${ }^{42}$ In the case of administrative agencies, which have convened a number of negotiated rulemaking (reg-neg) committees of stakeholders to negotiate draft rules in recent years, it is sufficient that the agency convene a "balanced" committee, review the rule developed by the committee, and subject it to normal agency decisional procedures. ${ }^{43}$

If state or federal governmental bodies in the United States were to mandate certification, questions regarding the applicability of antitrust law and administrative law would also arise. The antitrust issues, while too involved to discuss fully here, could probably be managed. In the first instance, many problems could likely be avoided by providing for competition among alternative certifiers. In addition, U.S. antitrust law has a general exception for anticompetitive conditions resulting from intentional state action. ${ }^{44}$ Thus, antitrust problems could be managed through clear, legislatively authorized policies providing for certifier competition and supervised by government agencies. ${ }^{45}$

The administrative law issues raised by mandated certification would divide among statutory and constitutional questions. The main constitutional question would be whether the Due Process Clause applies to certification processes. The U.S. Supreme Court has tended to narrow the definition of "state action" to which the clause applies in recent years. ${ }^{46}$ But it is not entirely clear that the rulemaking and adjudication involved in standard setting and certifica-

might respond to government proposals to enact their standards into law. I am indebted to John Shoaff for reminding me of this issue.

42. This is what the states often have done when privatizing prison administration. See, e.g., Ira P. Robbins, The Impact of the Delegation Doctrine on Prison Privatization, 35 UCLA L. REv.911, 942-50(1988).

43. As authorized by the Negotiated Rulemaking Act of 1990, 5 U.S.C. \$561. The statute requires the agency to exercise somewhat more control over the reg-neg process than described in the text, but this is not a constitutional requirement.

44. Parker v. Brown, 317 U.S. 341 (1943) (upholding a Califormia statute fixing the price of raisins).

45. California Retail Liquor Dealer's Ass'n v. Midcal Aluminum, Inc., 445 U.S. 97, 105-06 (1980) (defining the clear statement and state supervision criteria). Absent active and effective state involvement, however, firms participating in self-regulatory standard setting do face risks of antitrust liability. See, e.g., Allied Tube \& Conduit Corp. v. Indian Head, Inc., 486 U.S. 492 (1988) (holding the National Fire Protection Association (NFPA), a nongovernmental standard setting organization, liable for antitust violations, when steel manufacturers used its processes to prevent approval of plastic conduit as an alternative to steel in the NFPA's National Electrical Code, which was subsequently adopted by many govermmental bodies). See also FEDERAL TRADE COMM'N \& U.S. DOJ, GUIDELINES FOR COLlaborations AMONG COMPETTTORS (Apr. 2000), available at http://www.ftc.gov/os/2000/04/ftcdojguidelines.pdf (last visited Oct. 20, 2000).

46. See, e.g., Freeman, supra note 38, at 576-632; Alfred C. Aman Jr. Globalization and the U.S. Administrative Procedures Act: Furthering Democracy and the Global Public Interest, Bloomington Snyder Lecture, Lauterpacht Center for International Research, University of Cambridge (Feb. 3, 1999). Social Science Research Network Electronic Library, at http://papers.ssm.com/paper.taf?abstract_id $=176691$ (last visited July $19,2000)$ (copy on file with author). 
tion processes would be exempt. Thus, it is at least conceivable that certifiers would have to meet due process standards if certification were state mandated. That might not be particularly difficult, however, since due process requirements generally are not stringent, ${ }^{47}$ and since many nominally private organizations have already incorporated comparable procedures. ${ }^{48}$ Nonetheless, some certification programs might be prompted to open up their process somewhat under the glare of increased public scrutiny.

In the statutory realm, it is quite unlikely that statutes such as the federal Administrative Procedure Act $^{49}$ and similar state acts would be held to apply to certification processes as currently written. Most administrative procedure statutes apply only to acts of government agencies. Nothing, however, would preclude legislatures from making them applicable to certification processes. Moreover, it seems likely that if governments were to mandate certification they could eventually be persuaded to subject certification systems to administrative law-like procedural requirements. ${ }^{50}$

\section{B. Official Promotion of Certification}

Rather than "sticks," governments can use "carrots" to promote preferred policies. Given their ability to avert legal and political challenges based on delegation of law making powers while still altering environmental practices, government-provided incentives could turn out to be the preferred policy instrument for promoting certification. Several large U.S. administrative agencies either are considering or have made ISO 14001 certification one of their purchasing crite- ria. ${ }^{51}$ The U.S. Environmental Protection Agency (EPA) has promulgated a number of policies that explicitly or implicitly promote certification. Its enforcement policies, for example, while not directed solely at certification programs, indicate that environmental certification will be viewed as a positive factor in reviewing organizational compliance records. ${ }^{52}$ EPA's Office of Compliance Assurance and Monitoring is integrating EMS elements into its enforcement protocols and settlement criteria. ${ }^{53}$ The Agency has also used ISO 14001 in several of its Project XI multimedia permitting processes. ${ }^{54}$ In addition, EPA has published several doc. uments and handbooks assisting and promoting development of ISO 14001-style management systems for both industry and for local governments, ${ }^{55}$ and has supported research in support of the further deployment of EMSs. ${ }^{56}$

Most significantly, EPA recently instituted a new "Performance Track" program giving special treatment to firms meeting certification-like requirements. To qualify, companies must: (1) adopt and implement an EMS, (2) commit to improved environmental performance, (3) commit to public outreach and performance reporting, and (4) have a record of sustained compliance with environmental requirements. ${ }^{57}$ In addition to displaying the Performance Track logo, qualified companies enjoy streamlined monitoring, recordkeeping, and reporting under the Clean Air Act (CAA) $)^{58}$ and the Clean Water Act, ${ }^{59}$ and increased flexibility in installing "best available control technology" under

Corporate Guidelines for Environmental Violations, $\S \S 9 \mathrm{C1.2,} 9 \mathrm{Dl} .1$ (U.S. Sentencing Comm. 1993). Even the Overseas Private Investment Corporation has published draft guidance indicating that an ISO 14001 management system will help project sponsors demonstrate environmental monitoring and management capacity meeting its requirements for support. See United States International Development Cooperation Agency (ICDA), Overseas Private Investment Corporation (OPIC), Request for Comments on Draft Environmental Handbook; Notice, 63 Fed. Reg. 9696 (Feb. 25, 1998).

53. U.S. EPA, Draft EMS Action Plan for Public Comment (Dec. 20, 1999), available at EPA Reinvention http://www.epa.gov/ems/ plan99.htm (last visited Nov. 28, 2000).

54. One of the most recent is with Imation Enterprises Corporation, the world's largest manufacturer of magnetic data storage tapes. Id. at 15.

55. See,e.g., U.S. EPA, Office of Pollution Prevention and Toxics, Environmental Management Systems, at http://www.epa.gov/opptintr/ $\mathrm{dfe} /$ tools/ems/ems.html (last visited Nov. 27, 2000); U.S. EPA, Office of Wastewater Management, Environmental Management Systems: An Implementation Guide for Small and Medium-Sized Organizations, available at Environmental Management Systems/ISO 14001-Publications http://www.epa.gov/owmimet/wm046200.htm (last visited Nov. 28, 2000).

56. See, e.g., Position Statement on Environmental Management Systems and ISO 14001 and a Request for Comments on the Nature of the Data to Be Collected From Environmental Management System/ISO 14001 Pilots, 63 Fed. Reg. 12094-97 (Mar. 12, 1998), available at USEPA Federal Register Document http://www.epa.gov/fedrgstr/EPA-GENERAU 1998/March/Day-12/g6389.htm (last visited Nov. 26, 2000).

57. U.S. EPA, National Environmental Performance Track, at http://www.epa.gov/performancetrack (last visited Oct. 25, 2000).

58. 42 U.S.C. $\S \S 7401-7671 q$, ELR STAT. CAA $\S \S 101-618$.

59. 33 U.S.C. §§1251-1387, ELR STAT. FWPCA §§101-607. 
the CAA.$^{60}$ How significant this program will be in changing business practices remains to be seen. Yet it is important to note that by requiring improved performance and public performance reporting, EPA appears to be using it to get companies to go beyond the bare ISO 14001 requirements. This could in turm lead to a reshaping of the ISO and other certification programs over time.

There have been similar developments at the state level. Before EPA instituted the Performance Track program, Connecticut passed an "Act Concerning Exemplary Environmental Management Systems." The Act provides special benefits to companies that have: (1) registered ISO 14001 EMSs, (2) adopted approved principles of sustainability, and (3) good compliance records. The benefits include: (1) expedited permit review, (2) reduced fees, (3) less frequent reporting, (4) facilitywide permits for approved firms, and (5) public recognition of having attained this achievement. ${ }^{61}$ While it is difficult to track developments like this, other states might well adopt similar legislation. Whether they do or not, it is important to remember that favorable treatment of certified firms is only part of the government enforcement package that will best promote certification. The other part is effective enforcement of the environmental laws, which minimizes the relative economic disadvantages of certification for firms.

Government agencies can also promote the expansion of certification programs by subjecting themselves to them. A number of state and local agencies responsible for managing public forests have had their forests certified. Some have chosen the more environmentally and socially demanding FSC program, ${ }^{62}$ others the somewhat less protective AF\&PA program. ${ }^{63}$ The federal land management agencies appear to have no near-term intention of seeking third-party certification of their lands. ${ }^{64} \mathrm{EPA}$, by contrast,

60. U.S. EPA, National Environmental Performance Track, supra note 57.

61. See State of Connecticut, Substitute House Bill No. 6830, at http://www.cga.state.ct.us/ps99/Act/pa/1999PA-00226-R00HB-06830PA.htm (last visited Nov. 27, 2000). This provision, like much of the other information in this Article, came to my attention through the "voluntary codes" list-serve maintained by Kernaghan Webb. This is an invaluable source of information, and can be accessed at The Voluntary Codes Research Forum, at http://strategis.ic.gc.ca/SSG/ca00973e.html (last visited Nov. 28, 2000).

62. Thus far, the agencies responsible for managing state-owned lands in Minnesota, New York, and Pennsylvania have either achieved FSC certification or announced that they intend to do so. Margot Higgins, New York Forests Get Green Thumbs-Up, ENvTL. News NeTwORK, Feb. 5, 2000 , available at http://www.enn.com/enn-news-archive/2000/02/ 02052000/certification_9680.asp (last visited Nov. 28, 2000).

63. For example, Itaska and Lake counties, Minnesota. See Sustainable Forestry Initiative Program Licensees, at http://www.afandpa.org/forestry/ sfi/sfi_license.html (last visited Nov. 28, 2000).

64. See Forest Stewardship Council United States, Federal Lands Policy Statement Concerning FSC-Endorsed Certification on U.S. Federal Lands, at http://www.fscus.org/standards_policies/current_issues/federallands. html (visited July 19, 2000). An ironic part of the problem here is that national environmental groups have opposed certification of federal lands because they fear that certification would undermine their goal of a "zero cut" policy on federal lands.

65. See U.S. EPA, Draft EMS Action Plan for Public Comment, supra note 53; U.S. EPA, Code of Environmental Management Principles has put a considerable effort into promoting the use of ISO-style EMSs at all levels of government, including its own operations and those of other agencies, ${ }^{65}$ although government agencies of ten stop short of formal certification in order to minimize taxpayer expenses.

\section{Express Adoption of the Same or Substantially Similar Standards}

As noted above, independent enactment of certification standards would be one way of avoiding delegation doctrine problems. ${ }^{66}$ Because the states and the federal government share authority over environmental protection, adoption of certification standards could occur at either level. Moreover, it could be done either by legislatures, or by administrative agencies with broad substantive and procedural mandates. At the legislative level, no evidence of formal adoption of environmental certification standards has come to light during the preparation of this Article. ${ }^{67}$ In the past, however, many other types of privately generated standards have been adopted by North American legislatures. ${ }^{68}$ Given the inherent attractiveness of ready-made standards, environmental certification standards seem likely to become increasingly important in federal and state legislative processes over time. As that happens, legislatures doubtlessly will be tempted to change certification standards to reflect their particular concerns, as they have done with model legislation in other areas such as criminal and product liability law. ${ }^{69}$ On the other hand, pressure for interjurisdictional consistency in standards is growing, and privately generated international environmental standards could prove quite robust. ${ }^{70}$

At the administrative level, U.S. agencies have a long history of incorporating privately generated standards in

for Federal Agencies, 61 Fed. Reg. 54061-54066 (Oct. 16, 1996), possibly superseded by Greening the Government Through Waste Prevention, Recycling, and Federal Acquisition, Exec. Order No. 13101, 63 Fed. Reg. 49643 (Sept. 16, 1998), ELR ADMIN. MAT. 45100 (stressing recycling and pollution prevention practices rather than full blown EMSs).

66. Again there is a possible copyright problem in this scenario. See supra note 41.

67. However, Bolivia recently adopted forestry standards virtually identical to the FSC standards. Personal Communication, Dr. Dietrich Burger, Forestry Program, Deutsche Gesellschaft für Technische Zusammenarbeit (German Organization for Technical Cooperation), Eschborn (Feb. 28, 2000).

68. See generally Robert W. Hamilton, The Role of Nongovernmental Standards in the Development of Mandatory Federal Standards Affecting Safety or Health, 56 TEX. L. REv. 1329(1978). State and local legislatures have also adopted uncounted private codes in such areas as plumbing, construction, accounting practices, and the like. Id. at 1366.

69. Examples include the Model Penal Code, the Uniform Commercial Code, Restatements of Torts and Contracts, and the like.

70. The question of how much demand there is for interjurisdictional consistency is in fact quite complex. While some industrial interests operating in multiple legal jurisdictions have powerful interests in uniform standards, others, either operating in a narrower set of jurisdictions or having more capacity to vary performance according to locale, have equally strong interests in differential standards, which they have a comparative advantages in meeting. 
public regulations. Sometimes the private standards are small elements of rules covering larger topics, as in a Federal Trade Commission rule incorporating the American Society for Testing and Materials' standard for measuring gasoline octane in a rule requiring sellers to post octane ratings on their pumps. ${ }^{71}$ Other times agency rules are aimed at essentially the same issues as the private standards. When the Occupational Safety and Health Administration began operations in 1971, for example, it quickly converted a whole raft of voluntary health and safety standards into regulatory requirements. ${ }^{72}$ Other agencies have done the same. ${ }^{73}$ It is clear that EPA has often drawn upon nongovernmental standards in setting regulatory requirements, but there appear to be no published studies providing a comprehensive overview of how it has done this. In addition, the National Technology Transfer and Advancement Act of 1995 (NTTAA) requires that federal agencies "use technical standards that are developed or adopted by voluntary consensus bodies" and participate in their development where possible. ${ }^{74}$ The exact reach of the statute remains open to interpretation, particularly because it does not define key terms such as "technical standard" and "voluntary consensus body." 75 Nonetheless, it seems likely to exert a steady pull on agency practice over time.

It is also important to note that some environmental certification standards might be difficult for agencies to incorporate, because they include areas beyond the jurisdiction of any single agency. The FSC standards, for example, include indigenous rights, worker safety, and community economic concerns, in addition to environmental protection - concerns well beyond the jurisdiction of any single agency. Although some federal and state administrative agencies have been trying to achieve cross-agency policy

71. See, e.g., National Petroleum Refiners Ass'n v. Federal Trade Comm'n, 482 F.2d 672 (D.C. Cir. 1973), cert. denied, 415 U.S. 951 (1974).

72. The Occupational Safety and Health Administration's review of private standards was not always stellar, and it sometimes mandated standards that were either poorly developed or obsolete, such as a rule against ice in drinking water that derived from the days when all ice was obtained from frozen lakes and rivers. On the other hand, it also achieved considerable successes by using private standards. See Hamilton, supra note 68 , at 1388-99. Though over 20 years old, this study remains one of the few serious pieces of research ever to have been done on regulatory incorporation of privately set standards in the United States.

73. See id. at 1399-436.

74. National Technology Transfer and Advancement Act of 1995, 15 U.S.C. $\$ 3701$ (1996). The statute requires agencies to utilize voluntary standards unless doing so would be "inconsistent with law or otherwise impractical," and to report decisions not to use such standards to the Office of Management and Budget.

75. For a careful analysis of the statute and its possible effects on environmental regulation by EPA, see Shoaff, supra note 47 . It is also important to note that the Office of Management and Budget has promulgated a revised version of Circular A-1 19, which seeks to provide guidance to executive branch agencies on how to implement the Act. Office of Management and Budget, Circular A-119, Federal Participation in the Development and Use of Voluntary Consensus Standards and in Conformity Assessment Activities, 63 Fed. Reg. 8545 (Feb. 19, 1998). Shoaff's analysis explores a number of important ambiguities in the reach of the statute, particularly regarding what kinds of standards and standard-setting bodies are promoted by the statute. coordination in recent years, the going has been very difficult. ${ }^{76}$ This could conceivably mean either that nongovernmental programs have a significant long-term structural advantage over governmental programs, or that their efforts to integrate multiple concerns are too far ahead of governmental programs to be attractive to most industries.

Overall, the quality of legislative and administrative deliberation in adopting private standards has varied tremendously in different situations. Sometimes government bodies have carefully reviewed, evaluated, and appropriately amended private standards; other times they have not. ${ }^{77}$ When administrative agencies incorporate standards, they are subject to judicial review and must produce decisional records sufficient to persuade reviewing courts that their decisions were rational and based on adequate evidence. ${ }^{78}$ The NTTAA may make it somewhat easier for agency rules incorporating private standards to sustain judicial review, since it expresses a general preference for such standards, and puts a special burden on agencies to explain decisions in which they choose not to use them.

\section{Indirect Adoption Through "Environmental" Laws}

Some of the most important and difficult-to-trace forms of legal change unfold in informal processes. These processes include broad discussions in industrial, professional, and policy circles, ${ }^{79}$ as well as specific transactions among firms, regulators, ${ }^{80}$ and sometimes community organizations. ${ }^{81}$ It seems quite likely that environmental certification programs will affect regulatory programs through these almost invisible channels, beyond whatever changes are promulgated as official policy. Some tacit changes are likely to occur as inspectors evaluate practices at industrial facilities

76. See, e.g., Errol Meidinger, Organizational and Legal Challenges for Ecosystem Management, in CREATING A FORESTRY FOR THE 21sT Century: The Science of Ecosystem Management 361 (Kathryn A. Kohm \& Jerry F. Franklin eds., 1997).

77. See Hamilton, supra note 68 , at $1386-87$. It appears to be extremely common for state legislatures to include private standards in legislation by reference, sometimes providing that changes in the standards will automatically be mandated by the legislation. Id.

78. Several Consumer Product Safety Commission rules based on preexistent standards, for example, failed the 'substantial evidence' test on judicial review. Id. at 1401. Absent statutory directives to the contrary, agency rules are subject to the nominally less stringent "arbitrary and capricious" standard under the Administrative Procedure Act, 5 U.S.C. $\S 706(2)(a)$, though there is disagreement among scholars about whether there is really any difference between the two review standards.

79. An example is the growth of the field of "industrial ecology." See, e.g., ROBERT U. Ayers \& LESLIE W. AYERS, INDUSTRIAL ECOlOGY: Towards Closing the Material Cycle (1996); Thomas E. Graedel \& Braden R. Allenby, Industrial Ecology (1995).

80. See for example the negotiations described by KEITH HAWKINS, Environment and Enforcement: Regulation and the Social Definition OF POLLUTION (1984).

81. For a description of community participation, see R. Nils Olsen Jr., The Concentration of Commercial Hazardous Waste Facilities in the Western New York Community, 39 BufF. L. REv. 473 (1991). 
and question whether firms are following best practices. Others may come into play when permits go through revision cycles and regulators or public interest groups push for up-to-date standards. Regulatory officials can also promote certification standards in their choices of firms to inspect and monitor. Thus, they might decide to treat certification as an indicator of strong performance and to concentrate their enforcement efforts on other firms. ${ }^{82}$ As it becomes apparent in an industry that certified firms are likely to suffer fewer or less intensive inspections or to find it easier to get necessary regulatory approvals, the standard of practice in the industry would likely converge with that of the certification program.

In the Canadian "strict liability" regulatory regime certification standards may play an additional indirect role in shaping regulatory standards. The government can convict a firm of a violation simply by showing that the firm violated a standard, without offering any evidence on the overall quality of the firm's management. The firm can counter, however, with a "due diligence" defense, which involves showing that it exercised reasonable care under the circumstances. ${ }^{83}$ At least one Ontario court has treated failure to receive industry certification as failure of the due diligence defense. ${ }^{84}$ Certification standards have also been incorporated into law through remedies. In another Canadian case involving a violation of air pollution standards, the defendant proposed, and the judge accepted, a remedy requiring the defendant to achieve ISO 14001 certification. Of course, such certification was not a requirement of the regulations involved, but was incorporated through the equitable powers of the judge to impose an appropriate remedy. ${ }^{85}$

Finally, it should also be noted that international environmental law may become an important source of indirect incorporation of certification standards. Discussions about how to implement the Kyoto Protocol for the Reduction of Greenhouse Gasses, for example, include the possibility of using FSC forest certification to verify the maintenance of carbon retention "sinks," 14001 management systems to achieve reductions in greenhouse gas emissions. ${ }^{87}$ What role such mechanisms will in fact play remains open at present, but their proponents are

82. The appropriateness of preferential treatment for certified firms should not be presumed, however. At present there appears to be little empirical evidence that firms in certification programs generally perform better than uncertified firms. In the American Responsible Careß program, in fact, it appears that participants have reduced their pollution discharges no more quickly, and possibly more slowly, than nonparticipants. See Andrew King \& Michael Lenox, Industry Self-Regulation Without Sanctions: The Chemical Industry's Responsible Care Program, ACAD. MGMT. J. (forthcoming 2000) (copy on file with author). The authors hypothesize that this may reflect several factors, including the possible attractions of participation as a "smoke screen" for poorly performing firms and the failure of the program to apply significant sanctions to date. They note that the program is considering taking stronger action against poor performers and the possibility of implementing a third-party verification program to replace the current self-verification program. They also indicate that increased extemal scrutiny, whether by government, non-governmental organizations, or community members, could stimulate significant improvements in the effectiveness of the program.

83. Kernaghan Webb, Voluntary Initiatives and the Law, in VolunTARY actively promoting them as important tools for controlling global climate change.

In all of the above ways, certification programs can be incorporated implicitly into government regulatory systems without going through formal legislative or rulemaking processes. They effectively change the definition of proper behavior, and increase the rewards for compliance and the penalties for noncompliance with certification standards. Given the paucity of empirical research in the area, it is unclear to what extent certification standards in fact have been incorporated in legal systems through informal processes. Yet it is clear that we need to look carefully at certification programs in order to understand emerging requirements in environmental law.

\section{E. Indirect Adoption Through "Nonenvironmental" Laws}

Environmental certification standards can also be incorporated into legal systems through nominally nonenvironmental laws. This section lists some key areas where this is likely to happen.

\section{Tort Law}

Tort law sets standards for liability between parties who have not dealt with potential liability issues by contractual or other means. It usually applies to "accidents," often but not always between strangers. In general, U.S. tort law requires parties who fail to follow standards of "reasonable care" to compensate those who are foreseeably injured as a result. Certification standards can be expected to infuse several different areas of tort law.

\section{a. Toxic Torts}

The most obvious arena for potential incorporation is that of toxic torts, which involves liability for damage resulting from exposure to toxic environmental agents. The agents are usually chemicals, but can be biological organisms as well. ${ }^{88}$ Certification standards are most likely to apply to the question of what constitutes reasonable care. Both substantive and management system standards have the potential

Initiatives: The New Poltics of Corporate Greening 32, 33 ( $R$. Gibson ed., 1999).

84. See Regina v. Domtar, O.J. No. 3415 (Ont.C.J., Gen. Div.) (1993), as cited in Webb, supra note 83, at 45 n.5.

85. See Regina. v. Prospec Chems. Ltd., A.J. No. 174 (Alta. Prov. Ct.) (Jan. 25, 1996), as cited in Webb, supra note 83, at 46 n.7. The judge required the defendant to post a bond of $\$ 40,000$ subject to forfeiture if the company failed to comply with the certification order.

86. Forest Stewardship Council, Background Paper for FSC and Carbon Certification Workshop, available at FSC Website, supra note 2.

87. ISO Technical Committee 207 Climate Change Task Force, Application of the ISO 14000 Series of Standards to the Issue of Global Climate Change, Draft Third Interim Report, June 2000 (Document Reference: ISO TC 207 CCTF N29R3).

88. See, e.g., Gene J. Heady, Stuck Inside These Four Walls: Recognition of Sick Building Syndrome Has Laid the Foundation to Raise Toxic Tort Litigation to New Heights, 26 Tex. TeCH. L. Rev. 1041, 1053 (1995). 
for raising requirements. Consider the example of a firm that releases a toxic agent into a community and claims nonliability on grounds that its practices conformed to government regulations ${ }^{89}$ and industry standards. Plaintiffs could argue that the firm's lack of an ISO 14001 managementsystem constituted a failure to exercise reasonable care under the circumstances. Such an argument would be difficult for a defendant to counter, especially in light of the fact that a harmful release occurred.

Often the most difficult elements to prove in toxic tort suits are injury and causation. Environmental certification systems have the potential to aid plaintiffs in these areas too, since they may require firms to gather and maintain data on a broad array of environmental effects. These data would probably be subject to discovery by plaintiffs in a lawsuit in many jurisdictions and could help show chains of causation and injury. Although some states have enacted statutes to protect companies from compulsory disclosure of information generated in preparing voluntary environmental audits, such as would be done for ISO 14001 certification, many states and the federal government have not enacted such statutes. ${ }^{90}$

\section{b. Negligence}

Certification standards might also change liability standards for run-of-the-mill, nontoxic accidents. Consider the example of an auto accident triggered by road damage resulting from slumping earth where a firm harvested timber on steep slopes. Although government regulations might permit it, and other firms might engage in similar harvesting, prohibition by a program such as that of the FSC could be taken as persuasive evidence of failure to exercise due care. ${ }^{91}$ Again note that the firm could be liable whether it was certified or not. Thus, law would operate to extend "voluntary" standards to nonparticipants.

\section{c. Nuisance}

General standards for land use in Anglo-American law are defined through the law of nuisance, which generally prohibits uses of land that "substantially" and "unreasonably" interferes with the use and enjoyment of land by others. ${ }^{92}$

89. This is sometimes called the "regulatory compliance" defense. On the whole, U.S. courts have tended not to defer to regulatory standards in tort cases. They have been criticized for this tendency in recent years, and doctrine in the area may be undergoing some change. See generally Robert L. Rabin, Reassessing Regulatory Compliance, 88 GEO. L.J. 2049-84 (2000).

90. See Donald A. Carr \& William L. Thomas, Devising a Compliance Strategy Under the ISO 14000 International Environmental Management Standards, 15 PACE ENvTL L. Rev. 85, 191-205 (1997).

91. Although the issue is not central to this Article, note that the converse is also possible. Someone injured by a product or enterprise that met a privately set standard could sue the standard-setting organization in tort. Although U.S. courts traditionally eschew such suits, some important ones have been successful. See Shoaff, supra note 47, at 38 for an overview. See also Jeffrey Q. Smith et al., Products Liability Claims Against Voluntary Standards Developers-An Update on Recent Developments, at American National Standands Institute Website http://web.ansi.org/public/library/ guides/prod_liability.html (last visited Nov. 28, 2000).
Just what is unreasonable is hard to define, and depends on many factors (common practices in the area, priority in time, costs and benefits of the use, etc.). It is possible to anticipate, however, that in some instances certification standards, particularly substantive ones, could be called upon to define land uses as unreasonable. To offer a forestry example again, stream pollution that results from a clear cut larger than would be allowed by a certification system and that substantially affects the water quality of a downstream owner could potentially be cited as unreasonable, and enjoined by a court. The same might be true of air pollution suffered by downwind residents from a non-certified chemical plant. Thus again, certification standards would be drawn into the domain oflaw through general tort standards.

\section{d. Misrepresentation}

Tort law in the United States has long provided a cause of action to anyone physically injured as a result of reasonable reliance on a fraudulent misrepresentation made by one who is in the business of selling a product. ${ }^{93}$ The common-law requirement of physical harm is likely to limit the number of plaintiffs who can bring general common-law actions involving certification programs, ${ }^{94}$ but it is conceivable that some physical harm might result from misrepresentation of fact such as certification status and give rise to suits outside of the negligence framework. ${ }^{95}$

In any case, related statutory provisions regarding misrepresentation clearly provide actions for economic harm. The most important is a broadly worded provision of the federal "Lanham Act," creating general liability for commercial misrepresentation of goods or services to either
92. See generally Prosser \& KeETON, LAW OF TORTs (5th ed. 1984).

93. See Restatement (Third) of Torts: Products Liability \&42B (1998) ("one engaged in the business of selling or otherwise distributing products who, in connection with the sale of a product, makes a fraudulent, negligent, or innocent misrepresentation of a material fact conceming the product is subject to liability for harm to persons or property caused by the misrepresentation").

94. See id. \$21.

95. There have certainly been suits for misrepresentation of human rights records. One brought against clothing manufacturers operating in Saipan, for example, contributed to a fairly far-reaching settlement monitored by a U.S. not-for-profit organization. Monitoring Program: A Plan for Implementing Settlement on Apparel Production in Saipan, at http://www.globalexchange.org/economy/corporations/saipan/monitori ng.html (last visited Nov. 28, 2000). 
competitors or others who are damaged. ${ }^{96}$ It seems clear that this provision could be used in suits against firms said to be misrepresenting their certification status. It is even possible that it might be used against firms who claim to be managing their forests sustainably, but are not certified. Such suits could conceivably be brought by competitors who are certified, and who claim that theircompetitors are falsely implying that they are as well. ${ }^{97}$ Suits under this provision will certainly be worth watching! In addition, the Federal Trade Commission and various state attorneys general have the authority to brings suits against companies for commercial misrepresentation, and have often done so. ${ }^{98}$

\section{Property Law}

Property law in the United States allows land owners to make environmental management commitments that will continue to be binding even if the land comes under new ownership. One of the most important forms is the "conservation easement," through which an owner, while retaining possession of the land and the right to use it in many ways, can make specific commitments to another party regarding how the land will be used in the future..$^{99}$ The second party, which ordinarily must be a governmental or a not-for-profit organization, holds the "benefit" of the conservation easement. It has the power to determine whether the commitments are being met, and to take action to enforce them if they are not. Certification appears to be an excellent way of enforcing the kinds of conservation easements that allow continued management for activities such as forestry or low impact agriculture, but prohibit overharvesting, reductions of biodiversity, and the like. Using certification as an enforcement mechanism would considerably reduce the burden on benefit holders, and provide a "neutral," third-party assessment of how well the burdens of the easement are being met. Accordingly, it seems likely that drafters of conservation easements will discover the benefits of certification and begin incorporating them in the agreements.

A second area of property law where environmental certification could prove important is that of Native American rights. Principle 3 of the FSC program provides that "the legal and customary rights of indigenous peoples to own, use and manage their lands, territories, and resources shall be recognized and respected."100 Certifiers therefore are likely to be placed in the position of determining Native American claims not only to land, but also to hunting and fishing rights, in the course of certifying forest management units. It seems quite likely that they will have to make findings regarding Native American rights issues that have not been adjudicated by courts. It also seems likely that such findings will have significant effects on eventual legal definitions of native rights. ${ }^{101}$

\section{Tax Law}

Tax law could also become an important means of incorporating certification in the legal system. Conservation easements, for example, are often donated or sold to conservation organizations for very low prices. If the price received is less than the reduction in property value resulting from the transfer of the easement, ${ }^{102}$ that difference can qualify as a charitable deduction under federal income tax law ${ }^{103}$ and may bring additional tax benefits under state laws. Given the creativity of tax lawyers in arguing for deductions generally, it seems likely that other avenues in tax law will be probed in order to improve the financial benefits of certification.
96. Originally passed in 1946, the Lanham Act's false advertising provision was amended in 1988 to read as follows:

\begin{abstract}
Any person who, on or in connection with any goods or services, or any container for goods, uses in commerce any word, term, name, symbol, or device, or any combination thereof, or any false designation of origin, false or misleading description of fact, or false or misleading representation of fact, which is likely to cause confusion, or to cause mistake, or to deceive as to the affiliation, connection, or association of such person with another person, or as to the origin, sponsorship, or approval of his or her goods, services, or commercial activities by another person, or in commercial advertising or promotion, misrepresents the nature, characteristics, qualities, or geographic origin of his or her or another person's goods, services, or commercial activities, shall be liable in a civil action by any person who believes that he or she is or is likely to be damaged by such act.
\end{abstract}

15 U.S.C. $\$ 1125(a)(1)$.

97. For examples of the many kinds of suits that have been brought by competitors under the Lanham Act, see Jean Wegman Bums, Confused Jurisprudence: False Advertising Under the Lanham Act, 29 B. UYL. REV. 807 (1999).

98. See Lee Goldman, The World's Best Article on Competitor Suits for False Advertising, 45 FlA. L. REv. 487, 505-06 (1993).

99. The Uniform Conservation Easement Act defines a conservation easement as:

[a] nonpossessory interest of a holder in real property imposing limitations or affirmative obligations the purposes of which include retaining or protecting natural, scenic, or open-space values of real property, assuring its availability for agricultural, forest, recreational, or open-space use, protecting natural resources, maintaining or enhancing air or water quality, or preserving the historical, architectural, archaeological, or cultural aspects of real property.

Unif. Conserv. Easement Act, \& 1(1) (1981). The easement document ordinarily defines in much greater detail which uses will be allowed and which will not. See, e.g., JANET KIEHL \& ThOMAS Barrett, The Conservation Easement Hand book (1988). The easement is recorded in the file on the property that is maintained by the central registry in the local jurisdiction where the property is located.

100. FSC Website, supra note 2. Reprinted in Appendix.

101. For an overview of the issues in Canada, see Mark L. Stevenson \& Albert C. Peeling, Legal Memorandum Regarding Principle 3 of the Forest Stewardship Council's (FSC) Principles and Criteria, Prepared for the British Columbia Working Group, Forest Stewardship Council, May 10,2000 (copy on file with author). Although it does not discuss specific certification decisions, the memorandum concludes that national and regional standard-setting efforts have not dealt effectively with Native American rights questions thus far.

102. Conservation easements are generally expected to reduce the market value of property because they transfer some of its development potential away from the property.

103. 26 U.S.C. $\$ 170(h)$ (1994). 


\section{Information Regulation}

8

As the Lanham Act indicates, U.S. law tends to treat information relatively seriously. ${ }^{104}$ One very important statute in the environmental arena is the Emergency Planning and Community Right-To-Know Act (EPCRA) ${ }^{105}$ law, which requires users of specified toxic and hazardous chemicals to file annual reports disclosing names and quantities of chemicals either stored on site or released into the air, land, or water. ${ }^{106}$ Other laws require additional reporting of information on water ${ }^{107}$ and air pollution. ${ }^{108}$ Information reported under these statutes is generally available to the public from state and federal environmental agencies. Although it can be poorly coordinated and difficult to analyze, the value and accessibility of this information are likely to improve steadily as agencies implement modern, internet-oriented information systems as EPA has for the toxic release inventory under EPCRA. ${ }^{109}$ Moreover, if certification programs deliver on their promise to improve information production, management, and analysis in firms, those improvements may be reflected over time in new rules expanding public disclosure requirements. Finally, public reporting laws are likely to be important aids to public and private monitoring of the implementation of environmental certification programs in firms. By creating external capacity to compare certified firms to each other and to uncertified firms, it may also provide extra leverage for those pushing firms to become certified and certification programs to become stringent. ${ }^{110}$

\section{Financial Regulation}

U.S. financial regulation may be even more reliant on information disclosure than environmental regulation. Because the economic prospects of firms can be heavily affected by their environmental performance, financial regulation also has considerable potential to reinforce certification standards. Corporate disclosures are regulated both by detailed Securities and Exchange Commission (SEC) regulations, and by the general "anti-fraud" provisions of the securities laws, as well as by state laws. At present, the formal requirements of SEC rules are not particularly demanding regarding environmental issues. They tend to focus on potential legal liabilities of firms, and accord firms considerable discre-

104. One possibly important exception is continuing reliancè on industry self-regulation in the area of electronic commerce. This area remains very dynamic, and it is not clear either whether industry self-regulation will persist or whether it will have a significant influence on other areas.

105. 42 U.S.C. $\S \S 11001-11050$, ELR STAT. EPCRA §\$301-330.

106. Id. $\S \S 11022,11023$, ELR STAT. EPCRA $\$ \S 312,313$.

107. See, e.g., the Clean Water Act, 33 U.S.C. $\$ 1318$, ELR STAT. FWPCA $\S 308$.

108. See, e.g., 42 U.S.C. $\S \S 7619,7651$ k, ELR STAT. CAA $\S \S 319,412$.

109. See, e.g., the U.S. EPA, Toxic Release Inventory, at http://www.epa.gov/tri (last visited Oct. 25, 2000).

110. The King and Lenox research on the American Responsible Care $\$$ program suggests the potential power of public information reporting in assessing the effectiveness of certification programs. See supra note 82. tion in deciding what to report. ${ }^{111}$ However, certified firms are free to report their status, and many will do so. Such information is valuable both to general analysts assessing the likely profitability of firms and to green consumers seeking to distinguish between investment options based on environmental performance. SEC regulations mandate "generally accepted accounting principles," which are largely established by the profession itself through its own standards-setting process. ${ }^{112}$ While the long-term existence and relative success of this division of responsibility suggests the potential of environmental certification programs, the immediately relevant point is that it provides a potential mechanism for incorporating certification status into financial reporting. Whether and how this will happen remains to be seen. An important trend, however, is that financial reporting standards relating to environmental performance are currently subject to increased attention and debate in the United States. ${ }^{113}$ The critique that reporting standards are overly conservative regarding environmental performance appears to be gaining ground. To the extent that it prevails, both formally and informally, financial reporting may become an increasingly important channel for legal incorporation of environmental certification in the future.

\section{Trade Law}

The United States is a signatory to a number of intemational trade treaties, including the series of agreements referred to as the General Agreement on Tariffs and Trade (GATT). GATT requires, among other things, that "where technical regulations are required and relevant international standards exist or their completion is imminent, Members shall use them ... as a basis for technical regulations." ${ }^{.14}$ While this provision pushes governments to formally incorporate international standards in their positive laws, GATT is also likely to have broader informal incorporation effects over time. By presumptively privileging international standards, GATT may give international environmental certification programs implicit legal standing regardless of whether their standards are formally incorporated in the laws of member states. This is especially so because the World Trade Organization (WTO), GATT's primary trade regulation body, has

111. See generally John W. Bagby et al., So How Green Was My Balance Sheet?: Corporate Liability and Environmental Disclosure, 14 VA. ENVTL L.J. 225 (1995).

112. The standard-setting process is organized through the Financial Standards Accounting Board, which also has an Emerging Issues Task Force that deals with problems such as those in the changeable field of environmental accounting and reporting. See id. at 306-07.

113. Id. See also Cynthia A. Williams, The Securities and Exchange Commission and Corporate Social Transparency, 112 HARV. L. REV. 1197 (1999).

114. Agreement on Technical Barriers to Trade, Apr. 15, 1994, Marrakesh Agreement Establishing the World Trade Organization, Annex 1A, in Results of the Uruguay Round of Multilateral Trade Negotiations: The Legal Texts 20, 138 (GATT Secretariat, 1994). 
found it extremely difficult to promulgate rules to date. ${ }^{115}$ This situation virtually invites international nongovernmental standard-setting bodies to fill the vacuum as quickly as possible.

\section{F. Forbearance}

What does it mean when govemment legal systems take no direct action regarding certification systems? Inaction is to be expected when certification systems are new and government has little experience with them. After certification programs become better understood, however, government forbearance may begin to take on meaning. Most likely it will be taken to indicate tacit approval. It could even be seen as an implicit delegation of regulatory authority to the program. In practice, of course, it might simply be the case that legislatures and agencies see more pressing needs for scarce government resources in other areas. Intentionally or not, however, govemment forbearance could grow into a form of tacit delegation over time, making it increasingly unlikely that government will significantly expand its regulatory presence in the areas. Assuming there remains a societal expectation that some program is necessary, government forbearance may thus contribute to the long-term strengthening of environmental certification programs. Institutionally oriented observers would see them as having been incorporated into the social control system of which the formal legal system forms a part. That would have been accomplished with the assistance of the legal system by its essentially doing nothing!

\section{Legal Control of Certification Systems}

Legal systems can shape certification systems, and not merelyincorporate them. Indeed, like the EPA Performance Track Program, many of the legal incorporation mechanisms described above have the potential to affect the content and practice of certification as well. In general, certification systems are likely to be shaped in part with an eye to how legal systems may react.

\section{A. Informal Steering}

While government forbearance may be seen as a tacit form of approval or delegation, it can also be a tactical strategy for "steering" the development of certification programs. Regulatory officials and certification officials are likely to observe each other's behavior. Govermment agencies are likely

115. See, e.g., Marco Bronkers, Better Rules for a New Millennium: A Warning Against Undemocratic Developments in the WTO, 2 J. INT'L Bus. L. 547 (1999).

116. See Shoaff, supra note 47 , at 15,35 . See also U.S. GAO, Certification ReQuirements: New Guidance Should Encourage Transparency in Agency Decision Making, Report to THE Chairman, Committee on SMall Business, House of REPRESENTATIVES GAO/GCD-99-179 (Sept. 1999).

117. The federal govemment, for example, has passed a statutory framework authorizing the U.S. Department of Agriculture to regulate the certification of organic foods. Organic Foods Production Act of 1990, 7 U.S.C. $\$ 6501$ (2000). The department has yet to promulgate final standards under the Act, so many states have enacted their own programs. J. Howard Beales III, Modification and Consumer Information: Modern Biotechnology and the Regulation of Information, 55 FOOD \& DRUG L.J. 105, 117 (2000). See, e.g., FlA. Admin. Code AnN. 5h-19.004 (2000); IOWA ADMIN. CODE 21-47.1(190C) (2000). to be able to affect the substance and implementation of certification programs to some extent simply by how they signal they "might" react to them. Of course, this is simply the mirror image of certification programs trying to steer govemment policy, but it is important to note the capacity of govemment to affect programs by doing nothing yet giving signals about what it might do.

Govemments might also be able to steer certification programs by providing them with technical expertise, by actively participating in them, or by supporting research on their performance, all of which the United States is doing. ${ }^{116}$ In particular, they could gather and support the analysis of data regarding the relative performance of certification programs and firms within them. Governments can thereby simultaneously hedge their policy bets and enhance the transparency of certification programs. By thus facilitating increased production and dissemination of information, they may also increase the learning capacity of the regulatory system as a whole.

\section{B. Direct Regulation}

Should informal steering not suffice, governments always have the option of regulating certification programs. ${ }^{117}$ They might do this in a number of ways. First, they could redefine the substantive management standards that must be met by firms seeking to be certified. ${ }^{118}$ Of course, such an action would pose a dilemma for certification programs, particularly global ones, and they would have to decide whether to remain in business in the jurisdiction, try to get the law changed, ignore it, etc. Second, governments could impose rules governing the procedures followed by certification programs-standard-setting processes, certification processes, enforcement processes, etc. They might, for example, require more or different kinds of public participation in certification proceedings. ${ }^{119}$ They might require the disclosure of information that designers of certification processes planned not to disclose. ${ }^{120}$ Given the discretion vested in certifiers by many certification schemes, governments might also decide to define minimum qualifications for certifiers. In fact, governments could go so far as to develop public certification standards for private certification programs! Note that the Connecticut law discussed above carries the seeds of such possibilities within it.

118. It should also be noted that the standards for certified firms could continue to be different from those for noncertified firms.

119. Indeed, the U.S. antitrust laws already do so to some degree, by favoring standard-setting processes that are open, balanced, and transparent. See generally David A. Swankin, How Due Process in the Development of Voluntary Consensus Standards Can Reduce the Risk of Anti-Trust Liability, Prepared for the U.S. Dep't of Commerce, Nat'l Inst. of Standards and Tech., NIST-GCR-90-571 (1990); Shoaff, supra note 47, at 37.

120. Research done for the Administrative Conference of the United States in the early 1990s resulted in a recommendation that information of the kind discussed here generally should be made available to the public on the same terms as if the Freedom of Information Act applied. See Douglas C. Michael, Federal Use of Audited Self-Regulation as a Regulatory Technique, 47 ADMIN. L. REv. 171 app. (1995). 
There are many more possibilities. Two points should be kept in mind. First, certification programs perform public functions, functions that are most of ten carried out by government agencies under the types of rules listed above. Second, such forms of regulation have been imposed on other nongovernmental actors with public responsibilities, such as medical professionals, ${ }^{121}$ accountants, ${ }^{122}$ lawyers, and so on. There is no reason to assume that environmental professionals will enjoy permanent immunity.

\section{Inhibition of Certification Systems}

\section{National Trade Regulation}

Where industrial firms cooperate to setstandards governing themselves, potentially raising prices for their products or inhibiting entry into their industry, national fair trade laws, such as the U.S. antitrust laws, are always likely to be an issue. They have received considerable attention in development of certification programs to date. Often this attention has been private, with certification organizations seeking confidential advice from law firms and conducting confidential consultations with national-trade authorities. ${ }^{123}$ Other times it has been public, sometimes when certification programs explain why they cannot be more ambitious, ${ }^{124}$ and sometimes when they instruct participants on how to avoid antitrust problems. ${ }^{125}$ As noted in Section III, national trade laws can impose some constraints, but do not seem to be a major obstacle to certification programs at this time. ${ }^{126}$

\section{International Trade Regulation}

The past few years have seen a major expansion in the power of international trading institutions, which have used a series of international treaties to impose increasingly significant constraints on domestic regulatory programs. The WTO is currently responsible for implementing global trading policy by interpreting and applying GATT and recent important amendments on technical barriers to trade (TBTs). ${ }^{127}$ As noted in Section III, the GATT system is likely to be an importation mechanism for legal incorporation of certification systems. It can also pose some problems, however. The main issue facing environmental certification systems is whether they might be classified by the WTO as

121. The U.S. health care system, for example, involves a very complicated mix of nongovemmental regulation by the Joint Commission on the Accreditation of Hospitals and detailed regulation of the behavior health care professionals and specific aspects of health care provision. See, e.g., Timothy Stoltzfus Jost, The Joint Commission on Accreditation of Hospitals: Private Regulation of Health Care and the Public Interest, 24 B.C. L. Rev. 835 (1983); Steve P. Calandrillo, Physician-Assisted Suicide Under Managed Care, 26 J.L. MED. \& ETHICs 72 (1998).

122. See, e.g., Daniel L. Goelzer \& Susan Ferris Wyderko, Rule 2(E): Securities and Exchange Commission Discipline of Professionals, $85 \mathrm{Nw}$. U. L. REv. 652 (1991).

123. See, e.g., Webb, supra note 83 , at 42.

124. Private Environmental Regulation, supra note 2, at 66 (describing the AF\&PA's decision to employ a voluntary logger training program,
TBTs on grounds that they seek to differentiate among similar products based on how they are produced. Since the primary targets of the treaties are governments, some observers question whether nongovernmental certification organizations should be covered at all. The TBT amendments do apply to "recognized bodies"; however, this term is not defined in the treaty. ${ }^{128}$ Kernaghan Webb concludes that an organization like the ISO, with its designated national standards bodies, should be viewed as a recognized body, but that groups like the FSC should not. This makes some sense, but is also vulnerable based on the analysis of the paper thus far. "Recognition" could be given either a broad or a narrow interpretation. On the broad side, even forbearance from regulating based on an assessment that a certification program is performing acceptably could be viewed as recognition. On the narrow side, the WTO could conclude that unless a government explicitly delegates authority to regulate in a field to a certification program, it is not a recognized program. This is another area that will bear watching. The effects of the WTO on domestic legal incorporation of certification programs could be quite significant in years to come. And of course, if the WTO is treated as a form of legal systemeven though it is not a nation state, we must ask the question to what degree it incorporates certification programs.

\section{Conclusions}

\section{A. Patterns of Legal Incorporation}

Certification programs are natural targets for incorporation by legal systems because they have elements of formality, continuity, and institutionalization that other, ostensibly one-shot industry initiatives may not have, and also because they reduce the costs of deliberation and enforcement for legal bodies. Although the incorporation of environmental certification programs into U.S. law is only beginning to unfold, the analysis in Sections III and IV suggests that it is occurring, mostly through indirect legal processes. Yet the process of legal incorporation is very difficult to monitor. On the one hand, it can occur in so many small steps simultaneously in so many avenues that it is very difficult to trace. It can go forward almost unnoticed. On the other hand, there is a tension between the quasi-legal analysis performed above and empirical assessment. The facts that the forms of incor-

rather than a requirement that all suppliers be certified in sustainable forestry methods).

125. See Swankin, supra note 119 , at 32.

126. Their primary effects have been on so-called buyers groups, which are groups of wholesalers and retailer who jointly commit to buy only certified products. These groups have evidently been constrained in various ways by trade laws, but no published information has been found that explains how.

127. Agreement on Technical Barriers to Trade, supra note 114, at 6-7.

128. Annex I of the TBT Amendments defines "standard" as a "document approved by a recognized body, that provides, for common and repeated use, rules, guidelines or characteristics for products or related processes and production methods, with which compliance is not mandatory." Id. at 157. 
poration described above can occur, and are occurring, do not by themselves demonstrate that a widespread change is taking place. They indicate that larger changes may be occurring, though, and that it is appropriate to inquire further.

\section{B. Implications}

One of the primary reasons legal incorporation of certification is interesting is that it may signal larger shifts in social governance structures. The challenge is to grasp the dimensions of the change that are likely to be most important. To date, most analysis has focused on questions such as whether voluntary environmental programs yield environmental performance better than would have occurred otherwise, and whether they improve cost-effectiveness. Although the answers vary with specific cases, they seem to incline toward a cautious "yes."129 Provided certain safeguards are present, such as transparency and watchdog groups with the ability to monitor activities, environmental and efficiency gains can be achieved. ${ }^{130}$ And, of course, the fact that these gains are possible may be what impels the establishment of certification systems and other nongovernmental initiatives in the first place.

Yet, other dimensions of change may be equally or more important. For example, the proliferation and institutionalization of certification systems may signal a general shift in political power from some actors to others. Who exactly is gaining and losing power? Cutler, Haufler, and Porter, who have studied the growth of nongovernmental authority in a number of sectors, conclude that traditional nation states are clearly losing ground, while corporate industrial interests are gaining. ${ }^{131}$ They argue that this shift is bringing a diminution of public participation and accountability. ${ }^{132}$ In their even more expansive study, Braithwaite and Drahos agree that many nation states are losing ground to corporations and self-regulatory organizations in the emerging global regulatory system. ${ }^{133}$ They see the system as fluid and highly variable, however, depending on the particular area of regulation and problem. Actors pursue their agendas in significant part by hashing out guiding principles, and even relatively small-scale players encoun-

129. See, e.g., Voluntary Approaches in Environmental Policy (Carlo Carraro \& Francois Leveque eds., 1999). See also the papers collected at Second CAVA Workshop on the Efficiency of Voluntary Approaches to Environmental Policy, at http://www.akf.dk/cava/wp.htm (last visited Nov. 28, 2000).

130. Voluntary ApProaches in Environmental Policy, supra note 129 , at 10.

131. Private Authortiy and International Affairs 369-70 (A. Claire Cutler et al. eds., 1999).

132. Id.

133. John Braithwaite \& Peter Drahos, Global Business Regulation (2000). They see the United States and the European Union, however, as still the most powerful actors in the global regulatory system.

134. It is important to note, however, that many certification programs incorporate and build on legal requirements, often making it more likely that they will be met. Therefore their legitimacy cannot be treated as entirely separate from government authority.

135. Important exceptions include Cashore, supra note 6, and PrIvate ter a surprising number of strategic opportunities to affect the system. Nonetheless, the overall pattern is one of increasing control by large, powerful actors, working as of ten through private governance processes as through state ones.

The growth of a global regulatory system relying heavily on nongovernmental regulation also raises important questions about the nature of political legitimacy, and whether it might be changing. Received social theory holds that to survive governance systems must establish significant claims to legitimacy with the public. For perhaps two centuries governments have enjoyed a virtual monopoly on legitimate regulatory authority. How then do nongovernmental environmental regulatory systems establish and maintain legitimacy? One possibility, of course, is that they don't, because people simply do not understand how they work or how important they are. While this is true of some systems, which pretend to seek transparency while thwarting it in practice, it is not true of all of them. The ones reviewed in the research underlying this paper seem to be moving on the whole toward increased transparency. Moreover, they seem to enjoy growing public legitimacy and great confidence that it will continue to grow. It is therefore important to ask whether a new form of legitimacy may be emerging, one that is not based primarily on political processes managed by government. ${ }^{134}$ If so, perhaps it is based on the certification systems' peculiar combination of commitments to laudable but diffuse goals, high expertise, selective stakeholder participation, and independence from government. Plausible or not, this kind of hypothesis has received only the most preliminary exploration to date. ${ }^{135}$ If nongovernmental environmental certification systems flourish, such questions will have to be addressed. ${ }^{136}$

Fourth, as suggested above, voluntary agreements, certification programs, and legal incorporation may and perhaps should be seen in connection to larger developments in society. There has been a certain amount of work attempting to make such linkages to government legal institutions. Some approaches focus more on discursive processes in society, ${ }^{137}$ while others focus on organizational structures and patterns of relationships. ${ }^{138}$ The next step is to

Authority AND International Affairs, supra note 131. Private Authority and International Affairs focuses primarily on Weberian authority structures, which are probably more closely linked to nation states than is optimal for understanding the certification systems described here. Cashore focuses on generic modes of establishing and maintaining legitimacy, which are available to all types of networked social organizations, including certification systems.

136. It should also be noted that the question of legitimacy plagues both private certification systems and supranational govemmental entities, such as the WTO and the European Union, which also stand in some tension with nation states. See, e.g., Peter L. Lindseth, Democratic Legitimacy and the Administrative Character of Supranationalism: The Example of the European Community, 99 COLUM. L. REv. 628 (1999).

137. See, e.g., Teubner, supra note 25.

138. See, e.g., David M. Trubek et al., Global Restructuring and the Law: Studies of the Internationalization of Legal Fields and the Creation of Transnational Arenas, 44 CASE W. RES. L. REv. 407 (1994) (emerging systemic relationships, particularly the growth of a global trading order, may drive changes in both private and public legal orders). 
extend those theoretical constructs to nongovernmental regulatory systems, and to adapt them as appropriate.

Finally, it may be time to revisit the meaning of "law" and "legal system." As the discussion of international trade law suggested, the role of the nation state and state-based law is becoming increasingly problematical. It is being challenged from one side by the growth of a global trading system with an accompanying transnational legal system, and from the other by the growth of nongovernmental, often global regulatory mechanisms such as the certification systems. Yet the two supposedly defining characteristics of certification systems, their privateness and their voluntariness, are highly contingent. They are under serious threat as a result of the linkages of certification systems to national and transnational legal systems. They could turn into their opposites before we really notice it. If so, perhaps they were not what they seemed.

\section{Appendix}

\section{Examples of Forest Stewardship Council Principles and Standards}

The Forest Stewardship Principles and Criteria, applicable around the world, are as follows ${ }^{139}$ :

1. Forest management shall respect all applicable laws of the country in which they occur, and international treaties and agreements to which the country is a signatory, and comply with all FSC Principles and Criteria.

2. Long-term tenure and use rights to the land and forest resources shall be clearly defined, documented, and legally established.

3. The legal and customary rights of indigenous peoples to own, use, and manage their lands, territories, and resources shall be recognized and respected.

4. Forest management operations shall maintain or enhance the long-term social and economic well-being of forest workers and local communities.

5. Forest management operations shall encourage the efficient use of the forest's multiple products and services to ensure economic viability and a wide range of environmental and social benefits.

6. Forest management shall conserve biological diversity and its associated values, water resources, soils, and unique and fragile ecosystems and landscapes, and, by so doing, maintain the ecological functions and the integrity of the forest.
7. A management plan - appropriate to the scale and intensity of the operations-shall be written, implemented, and kept up to date. The long-term objectives of management, and the means of achieving them, shall be clearly stated.

8. Monitoring shall be conducted-appropriate to the scale and intensity of forest management - to assess the condition of the forest, yields of forest products, chain of custody, management activities, and their social and environmental impacts.

9. Management activities in high conservation value forests shall maintain or enhance the attributes that define such forests. Decisions regarding high conservation value forests shall always be considered in the context of a precautionary approach.

10. Plantations shall be planned and managed in accordance withPrinciples and Criteria 1-9, and Principle 10 and its Criteria. While plantations can provide an array of social and economic benefits, and can contribute to satisfying the world's needs for forest products, they should complement the management of, reduce pressures on, and promote the restoration and conservation of natural forests.

Exemplifying the countless standards and indicators implementing the principles and criteria are those of the Canadian Maritime Region regarding biodiversity that were promulgated as a regional application of Principle 6 above $^{140}$ :

6.2 * Safeguards shall exist which protect rare, threatened, and endangered species and their habitats (e.g. nesting and feeding areas). Conservation zones and protection areas, appropriate to the scale and intensity of forest management and the uniqueness of the affected resources, shall be established. Inappropriate hunting, fishing, trapping and collecting shall be controlled.

6.2.1 * Threatened and endangered species (listed by provincial and federal endangered species legislation) and their habitat must be protected or managed in accordance with approved recovery plans. Where recovery plans are not yet approved, disturbance of known occurrences of such species is to be avoided and a cautionary approach taken to protect their habitat. Forest owner/manager activities must ensure that species that are rare, vulnerable or under investigation by COSEWIC [Committee on the Status of Endangered Wildlife in Canada], or their provincial equivalents as designated by recognized authorities (e.g. academic experts, provincial or national museums or COSEWIC) are not further threatened by timber or non-timber activities.
Indicators:
Areas are inventoried for such species before harvest- ing, stand improvement or road-building activities are carried out (appropriate to the scale and intensity of the operation). Protection of such species is ad- dressed in the management plan. Known occurrences of such species and their habitat are not disturbed.

\section{FSC Website, supra note 2.}

140. Canadian Maritime Regional Initiative of the Canadian FSC
Working Group, Certification Standards for Best Forestry Practices in the Maritime Forestry Region, at http://www.web.net/fscca/standard. htm\#anchor79303 (visited 12/17/00). 
Forest workers are aware of known occurrences of such species and are following the management plan with respect to protecting such species and their habitat. Management staff is aware of those species that may occur locally.

6.2.2 * Old growth stands must not be harvested.

\section{Indicators:}

Inventories are carried out to identify old growth stands (appropriate to the scale and intensity of the operation). Old growth stands are identified on management plan maps. No evidence of harvesting old growth stands exists. Management and forest workers are aware of the characteristics of old growth stands.
6.2.3 * Areas with unusually high native species or ecosystem diversity must be identified, and protected or managed in such a way as to ensure that the diversity is not lost.

\section{Indicators:}

Management has identified areas with unusually high native species or ecosystem diversity using the latest regional methodology, formulae, and/or techniques (e.g. those used by WWF, Greater Fundy Ecosystem Research Group or New Brunswick Nature Trust). Such areas are identified on management plan maps. Management plans detail measures to ensure the diversity of such sites is not lost. Forest workers are following the management plan measures to ensure the diversity of such sites is not lost. 